\title{
Correction to: Assessment of stigma in patients with cystic fibrosis
}

Smita Pakhale ${ }^{1,2,3,4^{*}}$, Michael Armstrong ${ }^{1}$, Crystal Holly ${ }^{1,2,3}$, Rojiemiahd Edjoc ${ }^{1}$, Ena Gaudet ${ }^{2}$, Shawn Aaron 1,2,3, Giorgio Tasca, ${ }^{1,2,3}$, William Cameron ${ }^{1,2,3}$ and Louise Balfour ${ }^{2,3}$

\section{Correction to: BMC Pulm Med (2014) 14:76}

https://doi.org/10.1186/1471-2466-14-76

Following publication of the original article [1], the authors reported an error in Table 2 of the article.

Namely, rows '2.' and '9.' are missing from the table.

Please now see (the correct version of) Table 2 provided in this correction.

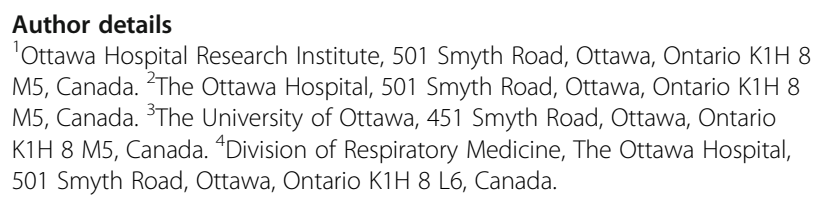

Published online: 20 May 2020

\section{Reference}

1. Pakhale S, Armstrong M, Holly C, et al. Assessment of stigma in patients with cystic fibrosis. BMC Pulm Med. 2014;14:76 https://doi.org/10.1186/14712466-14-76.

\footnotetext{
The original article can be found online at https://doi.org/10.1186/1471-2466$14-76$.

* Correspondence: spakhale@ohri.ca

'Ottawa Hospital Research Institute, 501 Smyth Road, Ottawa, Ontario K1H 8 M5, Canada

${ }^{2}$ The Ottawa Hospital, 501 Smyth Road, Ottawa, Ontario K1H 8 M5, Canada Full list of author information is available at the end of the article
}

(c) The Author(s). 2020 Open Access This article is licensed under a Creative Commons Attribution 4.0 International License, which permits use, sharing, adaptation, distribution and reproduction in any medium or format, as long as you give appropriate credit to the original author(s) and the source, provide a link to the Creative Commons licence, and indicate if changes were made. The images or other third party material in this article are included in the article's Creative Commons licence, unless indicated otherwise in a credit line to the material. If material is not included in the article's Creative Commons licence and your intended use is not permitted by statutory regulation or exceeds the permitted use, you will need to obtain permission directly from the copyright holder. To view a copy of this licence, visit http://creativecommons.org/licenses/by/4.0/ The Creative Commons Public Domain Dedication waiver (http://creativecommons.org/publicdomain/zero/1.0/) applies to the data made available in this article, unless otherwise stated in a credit line to the data. 
Table 2 The baseline CF Stigma Scale scores

\begin{tabular}{|c|c|c|c|c|}
\hline$N=45$ & $\begin{array}{l}\text { Strongly } \\
\text { Disagree = } 1 \\
\mathrm{~N}(\%)\end{array}$ & $\begin{array}{l}\text { Disagree = } 2 \\
\mathrm{~N}(\%)\end{array}$ & $\begin{array}{l}\text { Agree = } 3 \\
\mathrm{~N}(\%)\end{array}$ & $\begin{array}{l}\text { Strongly } \\
\text { Agree = } 4 \\
\mathrm{~N}(\%)\end{array}$ \\
\hline 1. I am very careful who I tell that I have CF. & $6(13.3)$ & $17(37.8)$ & $10(22.2)$ & $11(24.4)$ \\
\hline 2. I feel that I am not as good a person as others because I have CF. & $19(42.2)$ & $19(42.2)$ & $5(11.1)$ & $1(2.2)$ \\
\hline 3. Having CF makes me feel unclean. & $30(66.7)$ & $7(15.6)$ & $6(13.3)$ & $1(2.2)$ \\
\hline 4. Having CF makes me feel that I'm a bad person. & $37(82.2)$ & $6(13.3)$ & $1(2.2)$ & - \\
\hline 5. Most people think that a person with CF is disgusting. & $25(55.6)$ & $13(28.9)$ & $6(13.3)$ & - \\
\hline 6. Most people with CF are rejected when others find out. & $23(51.1)$ & $19(42.2)$ & $2(4.4)$ & - \\
\hline 7. I have been hurt by how people reacted to learning I have CF. & $22(48.9)$ & $11(24.4)$ & $2(4.4)$ & $1(2.2)$ \\
\hline 8. I have stopped socializing with some people because of their reactions to my having CF. & $23(51.1)$ & $13(28.9)$ & $7(15.6)$ & - \\
\hline 9. I have lost friends by telling them I have CF. & $27(60.0)$ & $15(33.3)$ & $2(4.4)$ & - \\
\hline 10. I worry that people who know I have CF will tell others. & $23(51.1)$ & $15(33.3)$ & $4(8.9)$ & $2(4.4)$ \\
\hline
\end{tabular}

